\title{
Synthesis of an optical catalyst for cracking contaminating dyes in the wastewater of factories using indium oxide in nanometer and usage in agriculture
}

\author{
Ishaq F. E. Ahmed", Ahmed I. El-Shenawy and Moamen S. Refat \\ Imam Abdulrahman Bin Faisal University, Department of Chemistry, College of Education, P.O. Box 1982, Dammam, \\ Saudi Arabia \\ "Corresponding author: e-mail: ismohammed@iau.edu.sa
}

\begin{abstract}
Herein, the photocatalytic degradation of the Congo Red (CR) and Crystal Violet (CV) dyes in an aqueous solution were discussed in the presence of an indium(III) oxide $\left(\operatorname{In}_{2} \mathrm{O}_{3}\right)$ as optical catalyst efficiency. The caproate bidentate indium(III) precursor complex has been synthesized and well interpreted by elemental analysis, molar conductivity, Fourier transform infrared (FT-IR), UV-Vis, and thermogravimetric (TGA) with its differential thermogravimetric (DTG) studies. The microanalytical and spectroscopic assignments suggested that the associated of mononuclear complex with 1:3 molar ratio $\left(\mathrm{M}^{3+}\right.$ :ligand). Octahedral structure is speculated for this parent complex of the caproate anion, $\mathrm{CH}_{3}\left(\mathrm{CH}_{2}\right)_{4} \mathrm{COO}^{-}$ligand. The $\mathrm{In}_{2} \mathrm{O}_{3} \mathrm{NPs}$ with nanoscale range within 10-20 nm was synthesized by a simple, low cost and eco-friendly method using indium(III) caproate complex. Indium oxide nanoparticles were formed after calcination of precursor in static air at $600^{\circ} \mathrm{C}$ for $3 \mathrm{hrs}$. The structural, grain size, morphological and decolorization efficiency of the synthesized NPs were characterized using the FT-IR, X-ray diffraction (XRD), scanning electron microscopy (SEM), energy dispersive X-ray analysis (EDX) and transmission electron microscopy (TEM) analyses. It was worthy mentioned that the prepared $\operatorname{In}_{2} \mathrm{O}_{3} \mathrm{NPs}$ showed a good photodegradation properties against $\mathrm{CR}$ and $\mathrm{CV}$ organic dyes during $90 \mathrm{~min}$.
\end{abstract}

Keywords: Photocatalyst; $\operatorname{In}_{2} \mathrm{O}_{3}$; precursors; Crystal Violet; Congo Red; NPs.

\section{INTRODUCTION}

The organic dyes are a plentiful class of organic compounds that exhibit increased environmental risk. Some of these dyes are harmful and carcinogenic ${ }^{1}$. Interactive dyes are widely used in the textile industry because of its wide variety of color shades, simplicity of application, brilliant colors and minimal energy consumption ${ }^{2}$. More attention has been paid recently to the study of the removal of dyes and pigments from industrial waste and sewage through adsorption using nanomaterials ${ }^{3,4}$. Organic and inorganic dyes are usually removed by different chemical and physical techniques, such as chemical reaction, electrolysis, reverse osmosis, adsorption, flocculation, ion exchange, membrane filtration, electrochemical destruction, precipitation and many more. Among all these techniques, adsorption technology has been found to be superior to other wastewater treatment techniques in terms of initial cost, simplicity of design, ease of operation and hypersensitivity to toxic substances ${ }^{5}$. Nanomaterials have gained importance in this category due to their expected surface area and improved interactive sites ${ }^{6}$.

The coordination of carboxylic acid towards metal ions has been the subject of an intensive research study due to its diverse applications, such as the suitability of metal carboxylic complexes as model systems for mineral sites in organic biochemistry ${ }^{7,8}$. In literature there are few articles discussed the metal complexation of caproic acid with rare earth metals ${ }^{9,10}, \mathrm{Cu}^{\mathrm{I}} / \mathrm{Cu}^{\mathrm{II}}$ oxides ${ }^{11}, \mathrm{Th}^{4+}, \mathrm{Pb}^{2+}$ and $\mathrm{Fe}^{3+12}$. The caproic acid play an important role as an analytical reagent for various metal ions e.g. $\mathrm{Zr}^{4+}$, $\mathrm{Cr}^{3+}, \mathrm{Mn}^{2+}, \mathrm{Ga}^{3+}$ and $\mathrm{Al}^{3+}$ in presence of chloroform solvent media and catechol violet indicator ${ }^{13-15}$.

Recently, the properties and applications of $\operatorname{In}_{2} \mathrm{O}_{3}$ oxide nanostructured have been studied on a large scale ${ }^{16,17}$. Indium(III) oxide display a wide band gap within 3.4-3.7
$\mathrm{eV}$ range ${ }^{18}$. It is a suitable candidate for the manufacture of various devices such as field effect transistors, light emitting diodes, blocker in tunnel intersections ${ }^{19}$, transparent conductive material in $\mathrm{LCDs}^{20}$ photovoltaic cells and solar cells ${ }^{18}$ gas Sensors ${ }^{21}$, 22. Various methods were used to prepared of $\mathrm{In}_{2} \mathrm{O}_{3}$ powders in nanostructured form and thin films ${ }^{23-26}$. This study aimed to investigate the crystalline structure, morphology and particle size of the synthesized $\mathrm{In}_{2} \mathrm{O}_{3}$ using FT-IR, XRD, SEM, EDX and TEM spectroscopic analyses. The photodegradation efficient of $\operatorname{In}_{2} \mathrm{O}_{3}$ NPs on the contaminated dyes (Congo Red and Crystal violet) in the wastewater were discussed dependently on different physical parameters as contact time, dose of adsorbent $\left(\operatorname{In}_{2} \mathrm{O}_{3}\right)$, and $\mathrm{pH}$ values. These experimental items were determined by UV-Vis spectrophotometer.

\section{EXPERIMENTAL}

\section{Chemicals}

The caproic acid $\left(\mathrm{CH}_{3}\left(\mathrm{CH}_{2}\right)_{4} \mathrm{COOH}\right)$ and anhydrous $\mathrm{InCl}_{3}$ were received from Fluka (UK) and Alfa Aesar chemical manufacturing company (USA), respectively. These chemicals used as received.

$\begin{array}{lcl}\text { Analyses } & & \\ \begin{array}{l}\text { I. Elemental analyses } \\ \text { II. Indium metal ion } \\ \text { percentage }\end{array} & \text { By } & \begin{array}{l}\text { Perkin Elmer CHN 2400 } \\ \text { Gravimetric analyses }\end{array} \\ \text { III. Molar conductivity } & \text { By } & \begin{array}{l}\text { Jenway } 4010 \text { conductivity } \\ \text { meter }\end{array} \\ \text { IV. FTIR spectra } & \text { By } & \begin{array}{l}\text { Bruker FT-IR } \\ \text { spectrophotometer }\end{array} \\ \text { V. Electronic absorption } & \text { By } & \begin{array}{l}\text { UV2-Unicam UV/Vis } \\ \text { spectrophotometer }\end{array} \\ \text { VI. Thermogravimetric } & \text { By } & \begin{array}{l}\text { Shimadzu TGA-50H } \\ \text { XPert Philips X-ray } \\ \text { VII. X-ray powder diffraction } \\ \text { diffractometer }\end{array}\end{array}$


VIII. SEM micrograph

IX. TEM micrograph
By Jeol Jem-1200 EX II Electron microscope

By JEOL 100s transmission electron microscope

\section{Synthesis of indium(III) caproate complex}

Indium(III) chloride ( $3 \mathrm{mmol}, 0.664 \mathrm{~g}$ ) was dissolved in $20 \mathrm{~mL}$ of bi-distilled water then mixed to $30 \mathrm{~mL}$ of an aqueous solution of caproic acid (9 mmol, $1.1 \mathrm{~mL}$ ) with contentiously stirring. The mixture was neutralized at $\mathrm{pH}=7.5$ using ammonia solution (10\%). The mixture was refluxed at $60^{\circ} \mathrm{C}$ for $2 \mathrm{hrs}$, then left to evaporate at room temperature overnight. The yellowish white precipitate was filtered, wash with hot water and little amount methanol solvent and dried at $60^{\circ} \mathrm{C}$. [ In$\left.\left(\mathrm{CH}_{3}\left(\mathrm{CH}_{2}\right)_{4} \mathrm{COO}\right)_{3}\right]$ complex, Anal.: (Calc.) Found, \%: C, (46.97) 46.55; H, (7.23) 7.19; In, (24.95) 24.71; yield $82 \% ; \Lambda_{\mathrm{M}}=2.1 \Omega^{-1} \cdot \mathrm{cm}^{2} \cdot \mathrm{mol}^{-1}$.

\section{Synthesis of the $\operatorname{In}_{2} \mathrm{O}_{3} \mathrm{NPs}$}

Calcination of the $\left[\mathrm{In}\left(\mathrm{CH}_{3}\left(\mathrm{CH}_{2}\right)_{4} \mathrm{COO}\right)_{3}\right]$ complex as a precursor material at temperature up to $600^{\circ} \mathrm{C}$ gives rise to nanocrystalline particles of $\operatorname{In}_{2} \mathrm{O}_{3}$ with nanoscale size.

\section{Photocatalytic degradation experiment}

A $250 \mathrm{~mL}$ conical flask including a $100 \mathrm{~mL}$ solution of the Congo Red or Crystal violet (Fig. 1) in water (50 $\left.\mathrm{mg} \cdot \mathrm{L}^{-1}\right)$ and $(50 \mathrm{mg})$ of synthesized $\mathrm{In}_{2} \mathrm{O}_{3}$ NPs. While the solution was stirred for approximately $1 \frac{1 / 2}{2} \mathrm{hrs}$ and then exposed to a UV lamp. The absorbances were measured each $15 \mathrm{~min}$. in a spectrophotometer at the maximum wavelength for the Congo Red (498 nm) or Crystal violet $(590 \mathrm{~nm})$. The decolorization rate of the dye was determined as expressed in Eq. (1):

Dye decolorization, $\%=\left(\mathrm{A}_{0}-\mathrm{A}_{\mathrm{t}}\right) / \mathrm{A}_{0} \cdot 100$

Where $A_{t}$ is the absorbance at requested time and $A_{0}$ is the initial absorbance of each solution.

$\mathbf{A}$

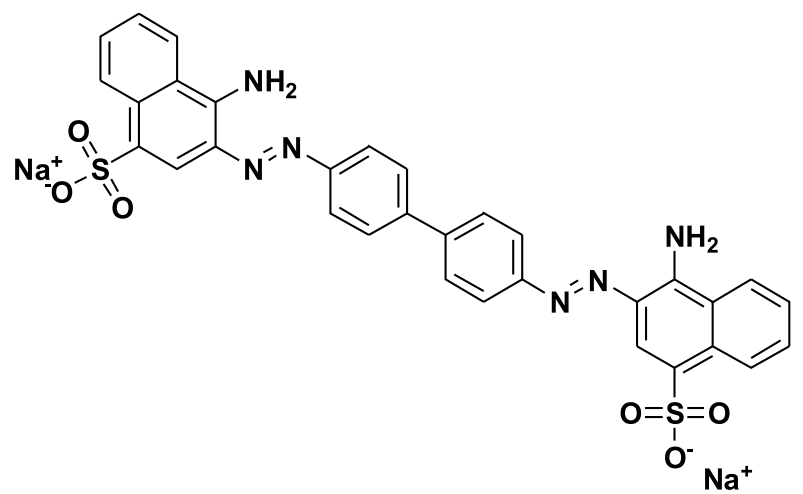

B

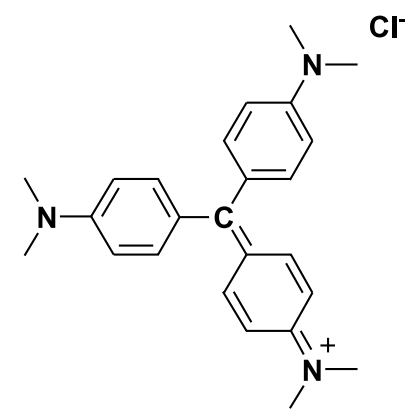

Figure 1. Chemical structures of A: Congo Red (CR) and B: Crystal violet $(\mathrm{CV})$ dyes

\section{RESULTS AND DISCUSSION}

\section{Characterization of $\left[\mathrm{In}\left(\mathrm{CH}_{3}\left(\mathrm{CH}_{2}\right)_{4} \mathrm{COO}\right)_{3}\right]$ complex precursor}

The main objective from the synthesized of indium(III) caproate complex is to be acquired of good precursors to prepared $\mathrm{In}_{2} \mathrm{O}_{3}$ oxide in nanostructure form. The new $\left[\mathrm{In}\left(\mathrm{CH}_{3}\left(\mathrm{CH}_{2}\right)_{4} \mathrm{COO}\right)_{3}\right]$ complex precursor was synthesized and well characterized using microanalytical, (FT-IR, UV-Vis) spectroscopy, thermal analyses. Elemental analyses results as seen from these data (experimental section), 1:3 (In : Ligand) binary complex was associated with good agreement matching between experimental and theoretical values. The results indicate that $\mathrm{CH}_{3}\left(\mathrm{CH}_{2}\right)_{4} \mathrm{COOH}$ ligand behave as uninegative bidentate molecule. This lose the carboxylate hydrogen atom on complexity with the indium(III) ion. The preparation of this binary complex (Fig. 2) can be proceed as follows:

$\mathrm{InCl}_{3}+3 \mathrm{CH}_{3}\left(\mathrm{CH}_{2}\right)_{4} \mathrm{COOH} \rightarrow\left[\mathrm{In}\left(\mathrm{CH}_{3}\left(\mathrm{CH}_{2}\right)_{4} \mathrm{COO}\right)_{3}\right]$ $+3 \mathrm{HCl}$

The structure of the indium(III) caproate complex suggested form the elemental analyses agree well with their proposed formula. The solubility of this complex display that its insoluble in most organic solvents (e.g. $\mathrm{CHCl}_{3}, \mathrm{C}_{6} \mathrm{H}_{6}, \mathrm{CH}_{3} \mathrm{OH}$, but soluble in DMF and DMSO solvents. The $\left[\mathrm{In}\left(\mathrm{CH}_{3}\left(\mathrm{CH}_{2}\right)_{4} \mathrm{COO}\right)_{3}\right]$ complex is dissolved in DMF and the molar conductivity of $10^{-3} \mathrm{M}$ solution at $30{ }^{\circ} \mathrm{C}$ is measured. It is deduced from the experimental result $\left(2.1 \Omega^{-1} \cdot \mathrm{cm}^{2} \cdot \mathrm{mol}^{-1}\right)$ that the indium(III) precursor complex is $1: 3$ nonelectrolyte ${ }^{27}$.

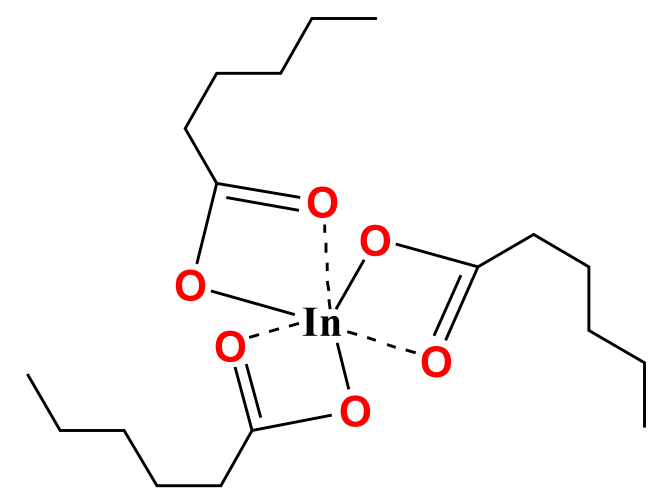

Figure 2. Chemical structure of indium(III) caproate complex

The FT-IR spectrum of the synthesized indium(III) caproate complex is shown in Figure 3. The FT-IR spectrum of free caproic acid, $\mathrm{CH}_{3}\left(\mathrm{CH}_{2}\right)_{4} \mathrm{COOH}$, display strong frequency band at $1700 \mathrm{~cm}^{-1}$ that is assigned to vibration motion of carbonyl $\nu \mathrm{C}=\mathrm{O}$ of $(\mathrm{COOH})$ group. This band is disappeared in case of FT-IR spectrum of the $\left[\mathrm{In}\left(\mathrm{CH}_{3}\left(\mathrm{CH}_{2}\right)_{4} \mathrm{COO}\right)_{3}\right]$ complex and it has been replaced by two new vibration bands at 1549 and $1402 \mathrm{~cm}^{-1}$ which are attributed to the asymmetric and symmetric vibration motions of the COO group, respectively ${ }^{28-30}$. Literature survey revealed that the carboxylate group can be chelated with any metal ions by three coordination modes as monodentate ( $\Delta v>$ ionic form), bidentate $(\Delta v<$ ionic form) or bridged bidentate $(\Delta v \approx$ ionic form) that $\left.\Delta v=v_{\mathrm{as}} \mathrm{COO}-v_{\mathrm{s}} \mathrm{COO}\right)^{\mathbf{1}}$. In case of infrared spectrum of indium(III) caproate complex, the $\Delta v$ difference frequencies is $147 \mathrm{~cm}^{-1}$. This value concluded 
that the carboxylate group coordinated to indium(III) ion through two oxygen atoms as bidentate binding mode $\mathrm{e}^{\mathbf{1 , 2}}$ (Fig. 2). There are two new absorption bands at 580 and $454 \mathrm{~cm}^{-1}$ attributed to the $v($ In-O $)$ frequencies ${ }^{30}$.

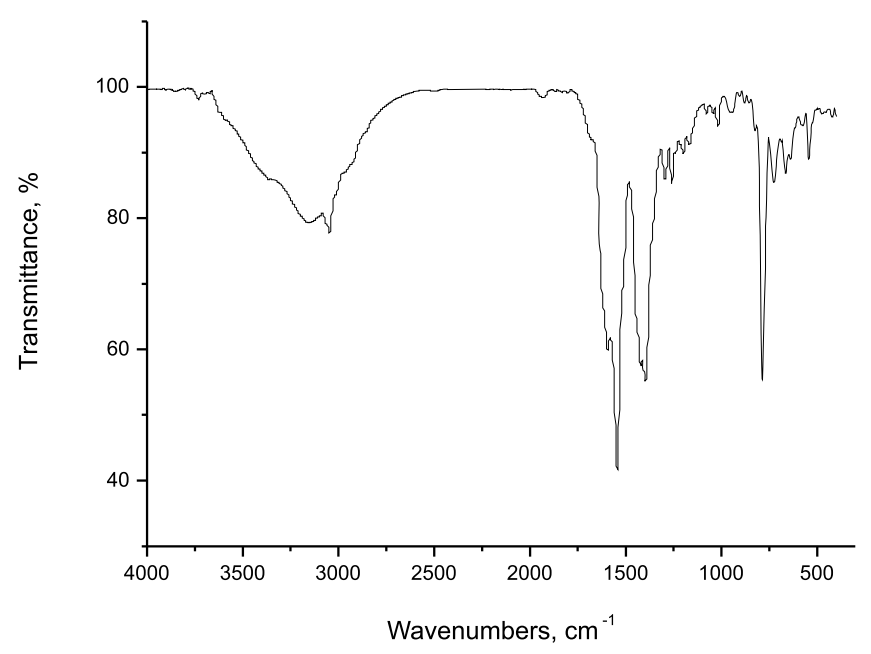

Figure 3. FT-IR spectrum of $\left[\mathrm{In}\left(\mathrm{CH}_{3}\left(\mathrm{CH}_{2}\right)_{4} \mathrm{COO}\right)_{3}\right]$ complex

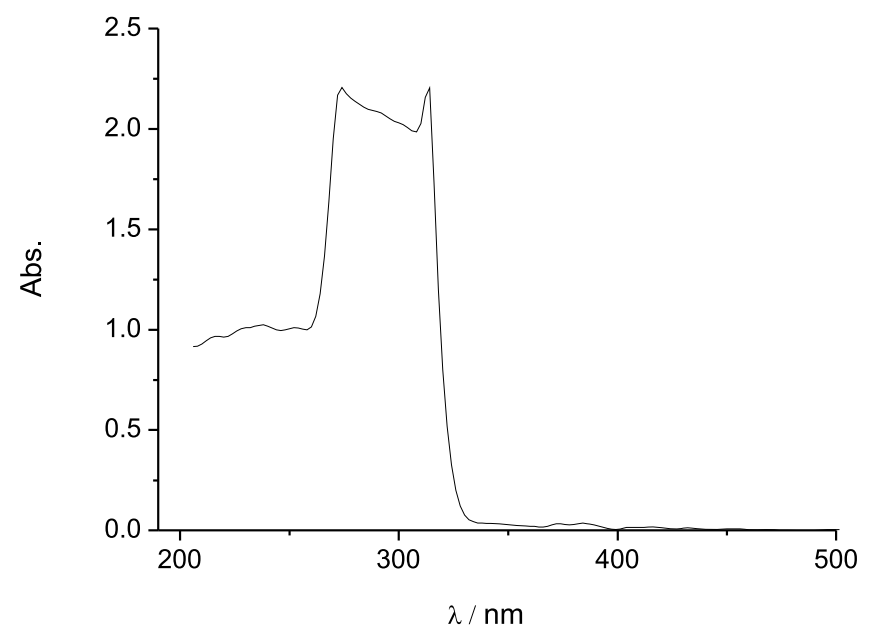

Figure 4. UV-Vis spectrum of $\left[\mathrm{In}\left(\mathrm{CH}_{3}\left(\mathrm{CH}_{2}\right)_{4} \mathrm{COO}\right)_{3}\right]$ complex

The absorption spectrum of the free $\mathrm{CH}_{3}\left(\mathrm{CH}_{2}\right)_{4} \mathrm{CO}$ $\mathrm{OH}$ acid ligand displayed two bands at 225 and $265 \mathrm{~nm}$ that were assigned to $\pi \rightarrow \pi^{*}$ and $\mathrm{n} \rightarrow \pi^{*}$ transitions of alkyl group $\left(-\mathrm{CH}_{3}\right.$ and $\left.-\mathrm{CH}_{2}\right)$ and carboxylic groups, respectively ${ }^{31}$. Normal absorption spectrum of indium(III) caproate complex (Fig. 4) show maximum absorption bands at $\mathrm{l}_{\max }=237,252,274,314$, and $383 \mathrm{~nm}$. The UV bands at 314 and $383 \mathrm{~nm}$ are attributed to metal charge-transfer and d-d transition ${ }^{\mathbf{3 2 - 3 4}}$. The relative increases in absorbance due to complex association at 274 and 314 $\mathrm{nm}$. This resulted data was supported the coordination of indium(III) ions via $\mathrm{COOH}$ group.

Thermal decomposition of indium(III) caproate complex was investigated based on controlled heating rate at $10^{\circ} \mathrm{C} \mathrm{min}{ }^{-1}$ under nitrogen atmosphere and weight loss was measured from room temperature until $800^{\circ} \mathrm{C}$. The TG-DTG curves (Fig. 5), displayed that the thermal degradation of $\left[\mathrm{In}\left(\mathrm{CH}_{3}\left(\mathrm{CH}_{2}\right)_{4} \mathrm{COO}\right)_{3}\right]$ complex passed in a broad peak at $\mathrm{DTG}_{\max }=499^{\circ} \mathrm{C}$. The total mass loss (Calc. $71.59 \%$, found $71.40 \%$ ) was attributed to the elimination of the three caproate organic parts of the indium(III) caproate complex. It is worthy mentioned that, indium(III) caproate complex decompose to
$1 / 2 \mathrm{In}_{2} \mathrm{O}_{3}$ oxide but the $\mathrm{In}(\mathrm{III})$ caproate complex has an intermediate step due to the association of indium(III) carbonate, $\operatorname{In}_{2}\left(\mathrm{CO}_{3}\right)_{3}$, at about $350^{\circ} \mathrm{C}$. This hypothesis is supported by the FT-IR spectrum (Fig. 6) resulted from calcinations of the indium(III) caproate complex at $350^{\circ} \mathrm{C}$, as refereed in Figure 6. So that, the proposed thermal degradation equation 2 is:

$$
\left[\mathrm{In}\left(\mathrm{CH}_{3}\left(\mathrm{CH}_{2}\right)_{4} \mathrm{COO}\right)_{3}\right] \rightarrow \mathrm{In}_{2}\left(\mathrm{CO}_{3}\right)_{3} \rightarrow \mathrm{In}_{2} \mathrm{O}_{3} \mathrm{Eq} \text {. }
$$

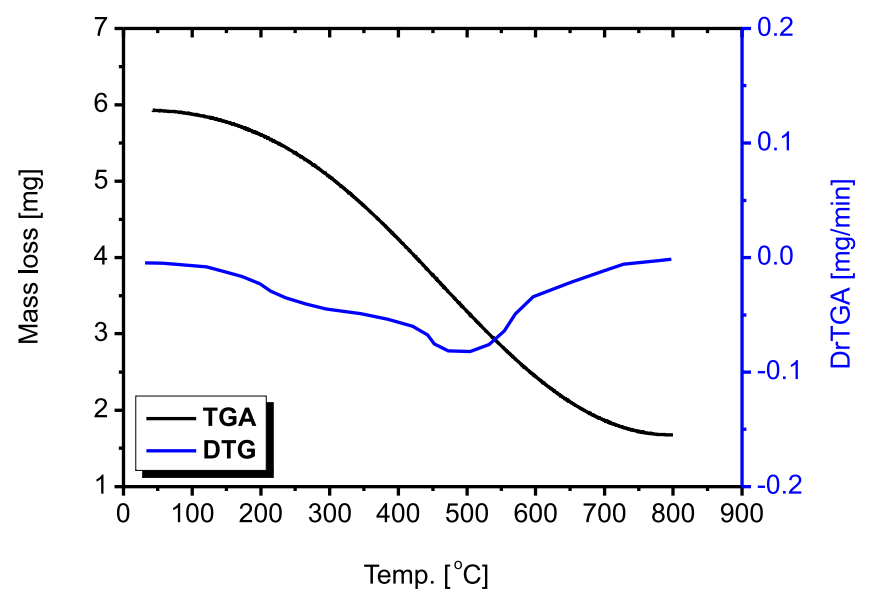

Figure 5. TGA diagram of $\left[\mathrm{In}\left(\mathrm{CH}_{3}\left(\mathrm{CH}_{2}\right)_{4} \mathrm{COO}\right)_{3}\right]$ complex

The kinetic thermodynamic parameters $\left(\mathrm{DG} / \mathrm{kJmol}^{-1}\right.$, $\mathrm{DH} / \mathrm{kJmol}^{-1}, \mathrm{DS} / \mathrm{Jmol}^{-1} \mathrm{~K}^{-1}, \mathrm{Z} / \mathrm{s}^{-1}, \mathrm{E} / \mathrm{kJmol}^{-1}$ ) have been elucidated for the differential thermogravimetric step DTG $_{\max } 499^{\circ} \mathrm{C}$ using Coats-Redfern ${ }^{35}$ and Horowitz-Metzger ${ }^{36}$ methods (Fig. 7). Both values of activation energy $\mathrm{E}^{*}$ and entropy $\mathrm{DS}^{*}$ of the reaction have been calculated using both methods and found to be in close agreement. The order of reaction in each case is one. The enthalpy of reaction has been calculated, using the $\mathrm{TG}^{37}$ and DTG curves, respectively ${ }^{38,39}$. The kinetic parameters for the thermal decomposition of the indium(III) caproate complex are given in Table 1. The activation energy of decomposition was found to be in the range $70-52.8 \mathrm{kJmol}^{-1}$. This high value of the activation energy reflect the thermal stability of the indium(III) caproate complex. The reaction for which $\Delta \mathrm{G}$ is positive and $\Delta \mathrm{S}$ is negative considered as unfavorable or as a non spontaneous reaction. The entropy of activation was found to have negative values in most the complexes which

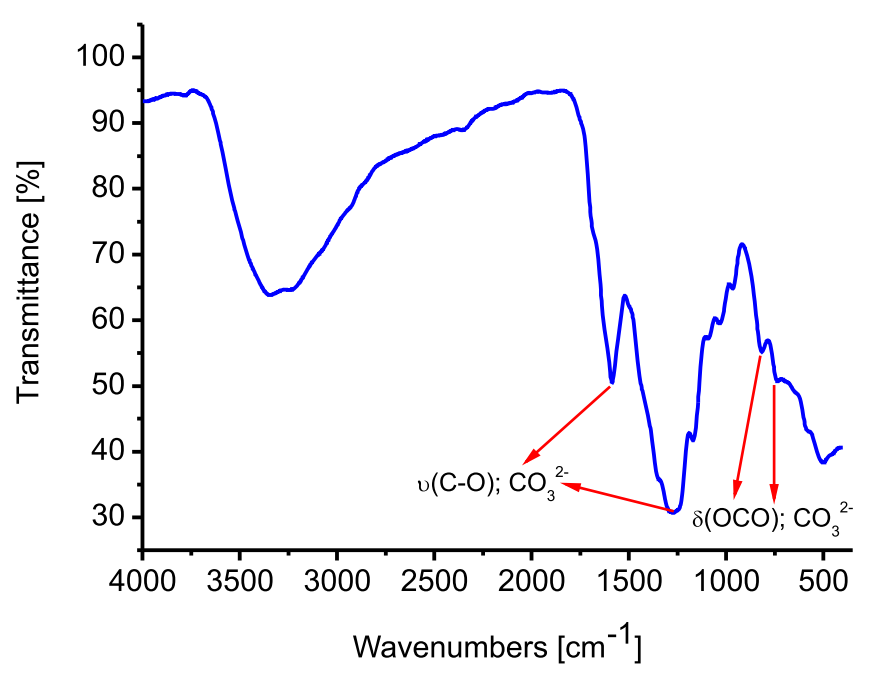

Figure 6. FT-IR spectrum of $\left[\mathrm{In}\left(\mathrm{CH}_{3}\left(\mathrm{CH}_{2}\right)_{4} \mathrm{COO}\right)_{3}\right]$ complex after calcinations at $350^{\circ} \mathrm{C}$ 
Table 1. Kinetic thermodynamic parameters based on Horowitz-Metzger (HM) and Coats-Redfern (CR) methods

\begin{tabular}{|c|c|c|c|c|c|c|c|c|c|}
\hline \multicolumn{5}{|c|}{ HM method* } & \multicolumn{5}{|c|}{ CR method* } \\
\hline$E$ & Z & $\Delta S$ & $\Delta \mathrm{H}$ & $\Delta \mathrm{G}$ & $\mathrm{E}$ & Z & $\Delta S$ & $\Delta \mathrm{H}$ & $\Delta \mathrm{G}$ \\
\hline 70 & $1.91 \mathrm{E}+02$ & -209 & 63.6 & 225 & 52.8 & $9.44 \mathrm{E}+00$ & -234 & 46.4 & 227 \\
\hline
\end{tabular}

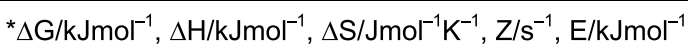

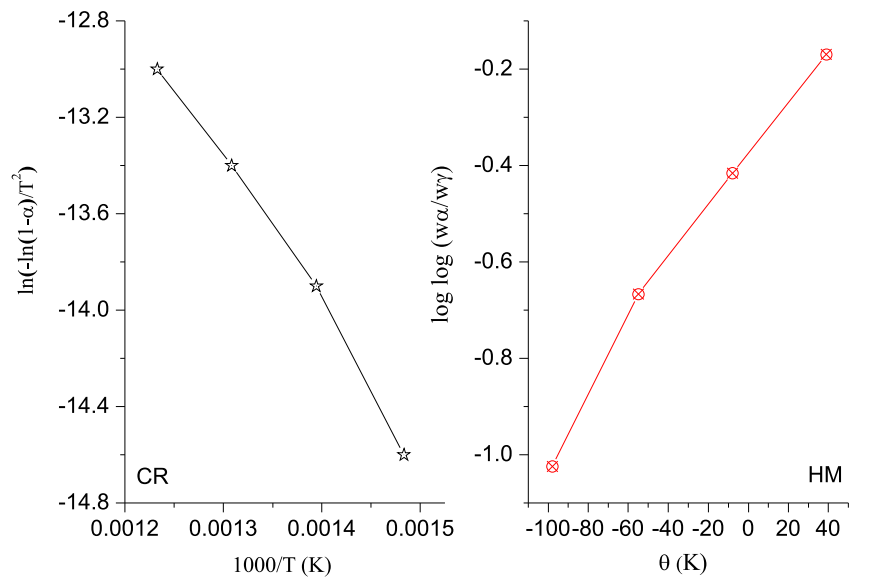

Figure 7. Kinetic thermodynamic $\mathrm{CR}$ and $\mathrm{HM}$ diagrams of $\left[\mathrm{In}\left(\mathrm{CH}_{3}\left(\mathrm{CH}_{2}\right)_{4} \mathrm{COO}\right)_{3}\right]$ complex

indicate that the decomposition reactions proceed with a lower rate than the normal ones. It is clear that the thermal decomposition process of studied complex is non-spontaneous, i.e., this complex is thermally stable.

XRD spectrum of the $\left[\mathrm{In}\left(\mathrm{CH}_{3}\left(\mathrm{CH}_{2}\right)_{4} \mathrm{COO}\right)_{3}\right]$ complex (Fig. 8) was measured within the $2 \theta=4-80^{\circ}$ range. This spectrum displayed that the synthesized indium(III) caproate precursor complex has a crystalline behavior. The new diffraction patterns presence in the spectrum of $\mathrm{In}^{(\mathrm{III})}$ caproate complex are due to the formation of chelation between caproic acid and indium ions. The maximum diffraction patterns of In $^{(I I I)}$ complex is exhibited at $2 \theta=16.8^{\circ}$. The particle size was calculated from XRD diagram by applying FWHM of the characteristic peaks using Deby-Scherrer equation ${ }^{40}, \mathrm{D}=\mathrm{K} \lambda / \beta \operatorname{Cos} \theta$ (where "D" term is the particle size of the crystal gain, " $\mathrm{K}$ " term is a constant ( 0.94 for copper grid), " $\lambda$ " term is the X-ray wavelength (1.5406 $\AA$ ), " $\theta$ " term is the Bragg diffraction angle and " $\beta$ " term is the integral peak width. The particle size of the synthesized complex was calculated based on the highest $2 \theta$ in comparable with

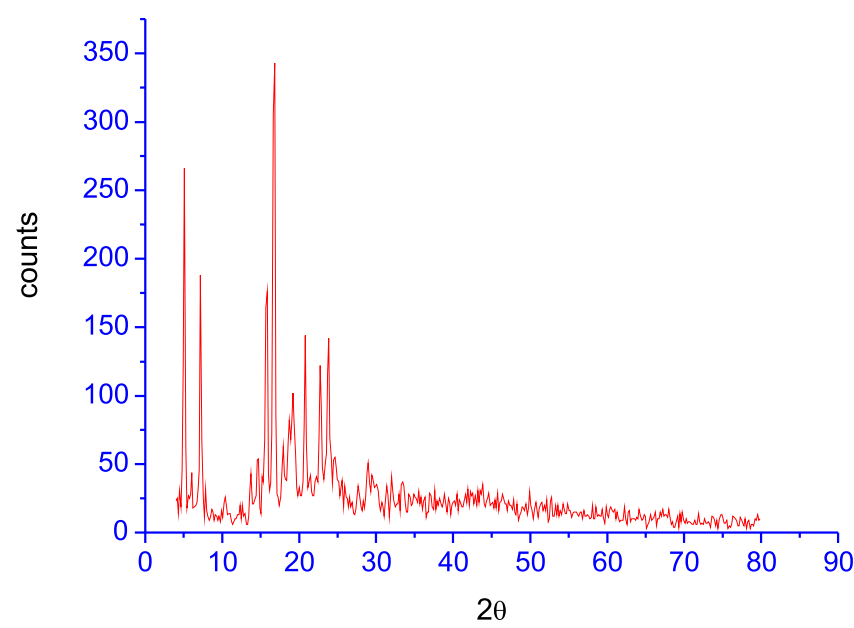

Figure 8. X-ray powder diffraction spectrum of [In$\left.\left(\mathrm{CH} 3 \mathrm{CH}_{2}\right)_{4} \mathrm{COO}\right)_{3}$ ] comple the other peaks. This value referred that the particle size exhibited at $(70 \mathrm{~nm})$ within nano scale range.

The examination of surface morphology of the [In$\left(\mathrm{CH}_{3}\left(\mathrm{CH}_{2}\right)_{4} \mathrm{COO}\right)_{3}$ ] complex was performed using SEM technique (Fig. 9). It can be seen that it gave a shape of the plates which are not compacted. This micrograph of indium(III) caproate complex indicated that the presence of well defined crystals free from any shadow of the impurities on the external surface. It is clearly from the SEM image that the synthesized In $^{(\text {III) }}$ complex, crystals were found to grow up from just a single molecule to several molecules in an aggregate distribution with particle sizes starting from a few nanometers to several hundred.

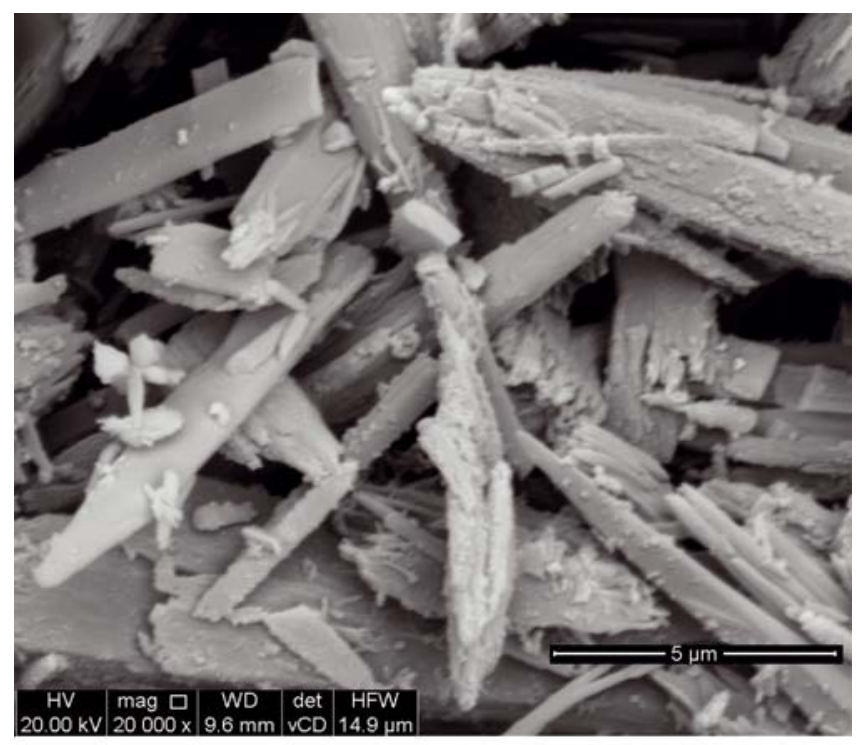

Figure 9. SEM image of $\left[\mathrm{In}\left(\mathrm{CH}_{3}\left(\mathrm{CH}_{2}\right)_{4} \mathrm{COO}\right)_{3}\right]$ complex

\section{Characterization of $\mathrm{In}_{2} \mathrm{O}_{3}$ oxide NPs}

This study describes the synthesis of $\operatorname{In}_{2} \mathrm{O}_{3}$ by the thermal decomposition route for the $\left[\operatorname{In}\left(\mathrm{CH}_{3}\left(\mathrm{CH}_{2}\right)_{4} \mathrm{COO}\right)_{3}\right]$ complex in static air. The discussions of the intermediate and the final thermal decomposition products were carried out by thermogravimetry, FT-IR spectroscopy, XRD, SEM, EDX, and TEM analyses. The analyses of these data show that the indium(III) caproate complex decomposed to $\operatorname{In}_{2} \mathrm{O}_{3}$ with the formation of an intermediate carbonate, $\operatorname{In}_{2}\left(\mathrm{CO}_{3}\right)_{3}$ compound. The $\mathrm{In}_{2} \mathrm{O}_{3} \mathrm{NPs}$ with crystallite size in the nanosize range was formed after calcination at temperature $800^{\circ} \mathrm{C}$. The suggested reaction occurring during the thermal decomposition of the indium(III) caproate complex is summarized below, according to TG/DTG and FT-IR results:

$\left[\mathrm{In}\left(\mathrm{CH}_{3}\left(\mathrm{CH}_{2}\right)_{4} \mathrm{COO}\right)_{3}\right] \underset{\text { Static } \mathrm{O}_{2} \text { gas }}{\stackrel{800}{\circ} \mathrm{C}} \mathrm{In}_{2} \mathrm{O}_{3}$

FT-IR spectrum of the synthesized $\operatorname{In}_{2} \mathrm{O}_{3}$ NPs by the thermal decomposition technique is shown in Figure 10. There are three distinguish vibration bands at 589 and $665 \mathrm{~cm}^{-1}$ were existed, these are attributed to the $v(\mathrm{In}-\mathrm{O})$ 
stretching and $\delta(\mathrm{In}-\mathrm{O}-\mathrm{In})$ bending vibrations, respectively in cubic $\mathrm{In}_{2} \mathrm{O}_{3}$ structure ${ }^{41-43}$. This result support that the phase formation is complete for the as-prepared $\mathrm{In}_{2} \mathrm{O}_{3}$ NPs and there is no evidence for the presence of any organic impurities in the synthesized indium(III) oxide sample. On the other hand, the presence of broad band at $3434 \mathrm{~cm}^{-1}$ and medium band at $1642 \mathrm{~cm}^{-1}$ can be assigned to the stretching and bending vibrations of the $v(\mathrm{O}-\mathrm{H})$ bands regarding water moisture.

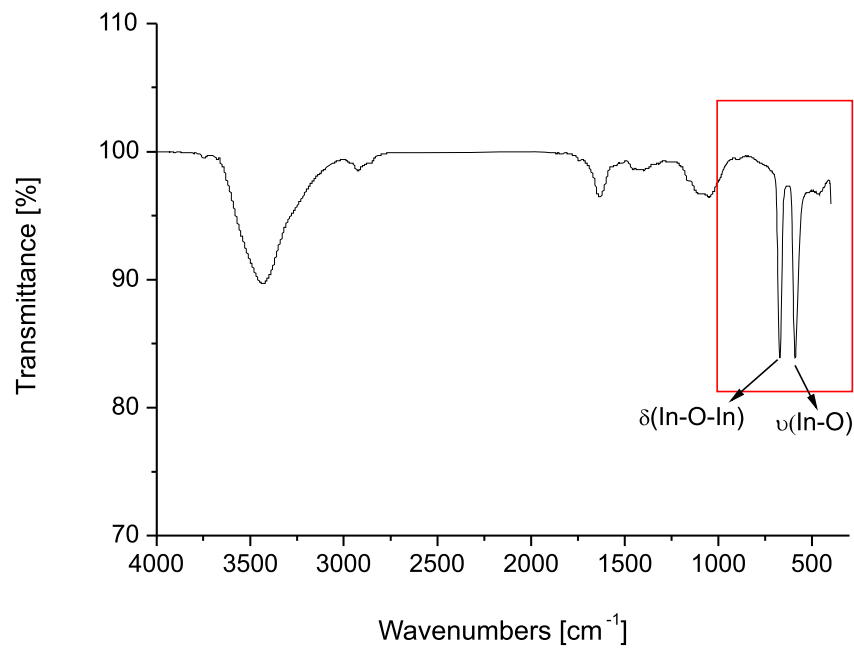

Figure 10. FT-IR spectrum of indium(III) caproate complex calcined at $800^{\circ} \mathrm{C}$ for $3 \mathrm{hrs}$

The electronic UV-Vis spectrum of synthesized $\mathrm{In}_{2} \mathrm{O}_{3}$ NPs was used to calculate the energy gap " $\mathrm{E}_{\mathrm{g}}$ ". The spectrum display absorption band at $347 \mathrm{~nm}$ (Fig. 11). The $\mathrm{E}_{\mathrm{g}}$ value was estimated using the wood and Tauc plot $^{44}$ as referred in the following equation 3:

$\alpha h v=\mathrm{A}\left(\mathrm{h} v-\mathrm{E}_{\mathrm{g}}\right)^{1 / 2} \mathrm{Eq}$.

where "A" term is a constant, "hv" term is the photon energy, and " $\mathrm{E}_{\mathrm{g}}$ " term is the energy gap. Plotting $(\alpha h v)^{2}$ as a function of photon energy, and extrapolating the linear portion of the curve to the absorption equal to zero as shown in the insets of Figure 11 give the value of the direct band gap $(E \mathrm{~g})$ to be $2.99 \mathrm{eV}$ for the $\mathrm{In}_{2} \mathrm{O}_{3}$ sample calcined at $800^{\circ} \mathrm{C}$. This value is less than that of $\sim 3.6 \mathrm{eV}$ for the $\mathrm{In}_{2} \mathrm{O}_{3}$ mentioned in the literature ${ }^{45-47}$. This value indicate the semiconductor behavior of $\operatorname{In}_{2} \mathrm{O}_{3}$ that can be used in photocatalyst applications ${ }^{46,47}$.

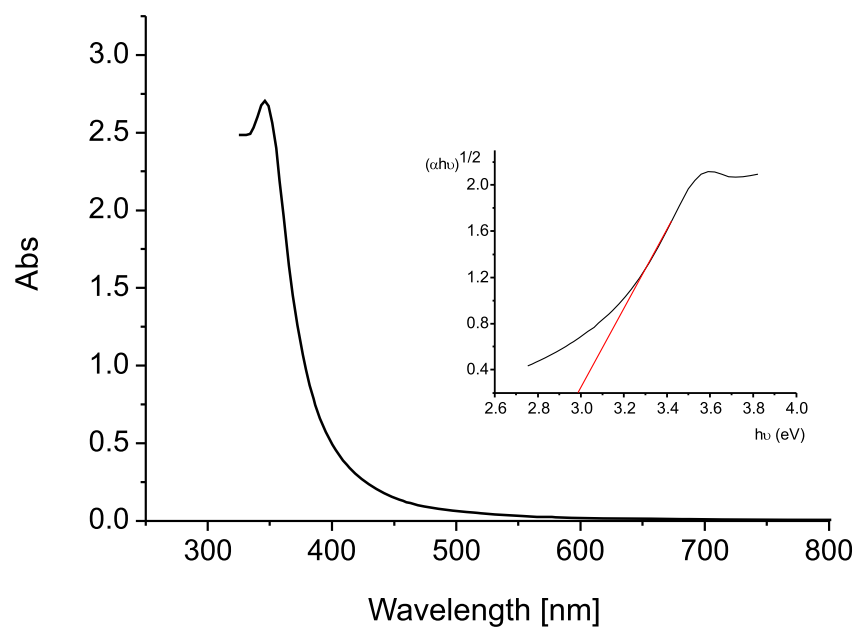

Figure 11. UV-Vis spectrum and energy band gap plots of the synthesized $\mathrm{In}_{2} \mathrm{O}_{3}$ NPs
The X-ray powder diffraction patterns of the indiu$\mathrm{m}(\mathrm{III})$ caproate complex after calcination at $800^{\circ} \mathrm{C}$ for 3 hrs is shown in Figure 12. The distinguish patterns attributed to cubic structure indexed on ICDD card $6-416^{\mathbf{4 8}}$. Figure 12 shows the strong and sharp diffraction patterns reveal that the $\operatorname{In}_{2} \mathrm{O}_{3}$ NPs has a well crystalline structure. The diffraction patterns agree with those given in JCPD card 6-416 of cubic $\operatorname{In}_{2} \mathrm{O}_{3}$ reflections as 211, 221, 222, 400, 413, 440, and 622 planes. Calculation of particle size of indium oxide using Scherrer's equation gives $20 \mathrm{~nm}$ value, confirmed that the particle size of the $\mathrm{In}_{2} \mathrm{O}_{3}$ which was prepared by thermal decomposition method of indium(III) caproate complex is in the nanosize range $<100 \mathrm{~nm}$.

The morphology of $\mathrm{In}_{2} \mathrm{O}_{3}$ NPs was investigated with SEM as shown in Figure 13. SEM micrograph (Fig. 13) reveals the overall appearance of indium(III) caproate complex calcined at $800^{\circ} \mathrm{C}$ for 3 hrs. The particles are nearly thick threads in shape has uniform size and distribution with symmetrical sizes, might be due to distribution of temperature during calcinations. It can be observed that product aggregation is constituted by many regular particles with a variety of porosity due to the evolution large amount of gases during synthesis. The porosity of $\mathrm{In}_{2} \mathrm{O}_{3}$ NPs facilitates and enhances the adsorption properties. The EDX analysis (Fig. 13) exhibited clear distinguish peaks of both indium and oxygen elements from the desired detected site. The atomic percentages of these elements are $82.71 \%$ and $17.29 \%$ for indium and oxygen, respectively.

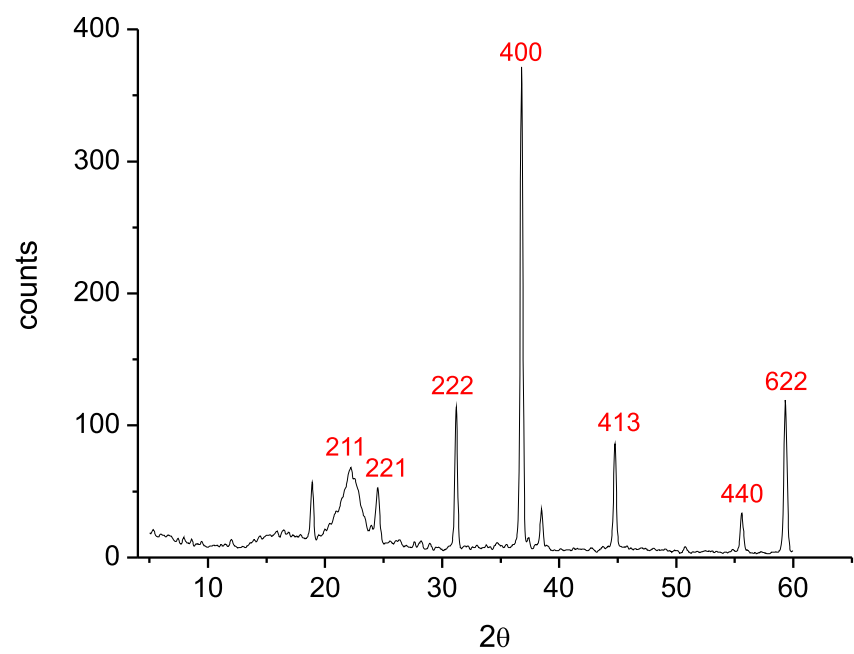

Figure 12. XRD diagram of the synthesized $\mathrm{In}_{2} \mathrm{O}_{3}$ NPs by calcined indium(III) caproate complex at $800^{\circ} \mathrm{C}$ for $3 \mathrm{hrs}$

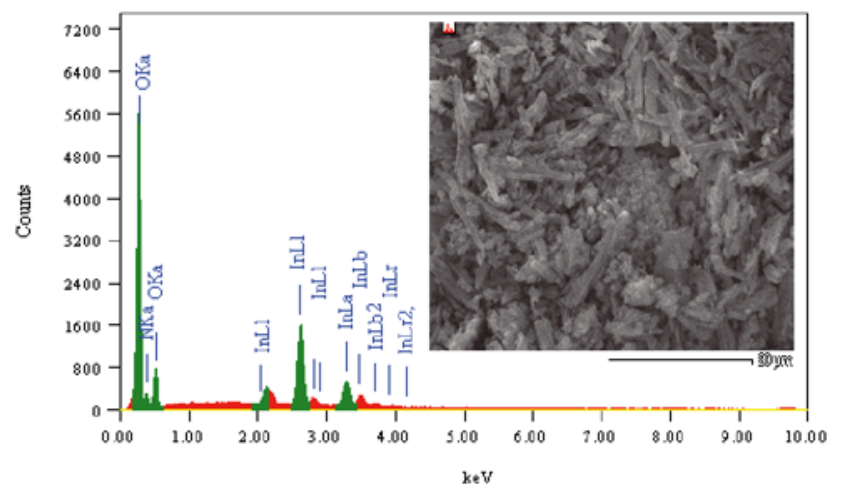

Figure 13. EDX spectrum and SEM image of the synthesized $\operatorname{In}_{2} \mathrm{O}_{3}$ NPs 


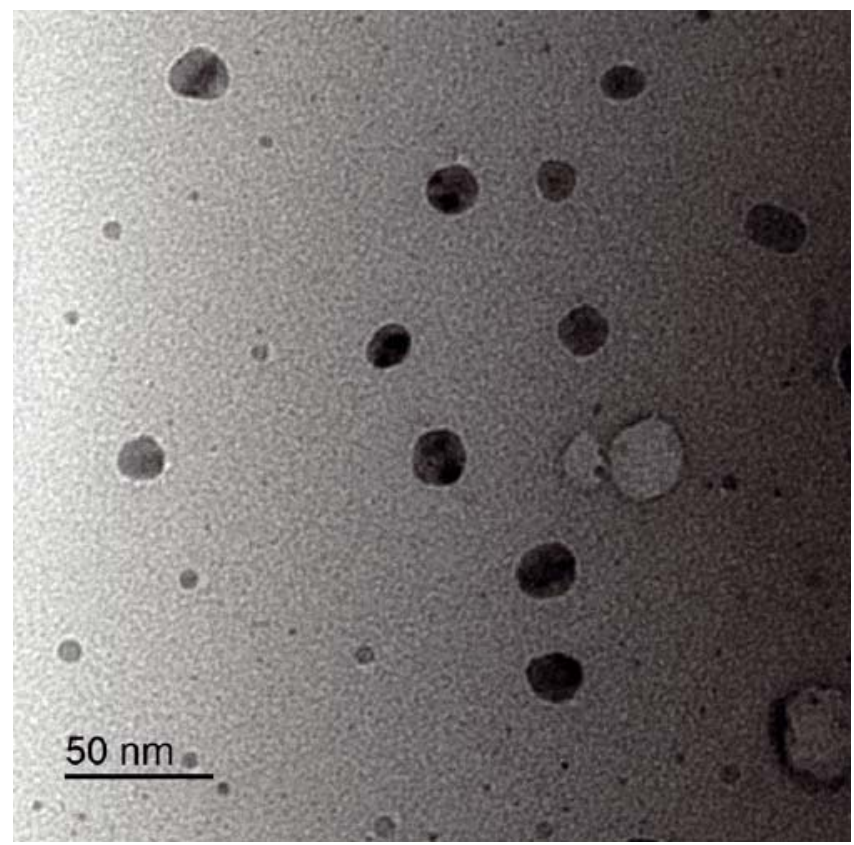

Figure 14. TEM image of the synthesized $\operatorname{In}_{2} \mathrm{O}_{3}$ NPs

Figure 14 shows a presented TEM image of the indiu$\mathrm{m}$ (III) caproate complex after calcination at $800^{\circ} \mathrm{C}$ for 3 hrs. The morphology of particles observed in the bright-field image is characterized by agglomerated NPs, most of them having a spheroidal shape. The particle size of the $\operatorname{In}_{2} \mathrm{O}_{3}$ NPs estimated by XRD was in agreement with the particle size obtained by TEM analysis $(10-20 \mathrm{~nm})$.

\section{Photocatalytic degradation properties}

In our study, the prepared $\operatorname{In}_{2} \mathrm{O}_{3}$ nanoscale size can be used as a photocatalyst smart material for the photodegradation of Congo Red (CR) and Crystal Violet $(\mathrm{CV})$ organic dyes which are found in the wastewater of factories and rehabilitated for use in agriculture. The photocatalytic data of the $\operatorname{In}_{2} \mathrm{O}_{3}$ NPs confirm that the degradation of these dyes after $90 \mathrm{~min}$ for the UV-irradiation reached the maximum results $\approx 93 \%$, and 95\% for the CR and CV, respectively. The photocatalytic degradation experiments were operated at i-different contact time, ii-dose of $\operatorname{In}_{2} \mathrm{O}_{3}$ NPs adsorbent, and iii-effect of $\mathrm{pH}$.

\section{Effect of time}

The effect of time on the degradation of $\mathrm{CR}$ and CV dyes onto $\mathrm{In}_{2} \mathrm{O}_{3}$ NPs adsorbent was investigated spectrophotometrically. These results are clearly displayed in Figure 15, which the degradable of industrial dyes (CR \& CV) increased with the increasing of contact time of $90 \mathrm{~min}$. The rate of adsorption is very fast at first with most of the compound being condensed during the first 45 minutes. It was found that more than $>40 \%$ adsorption dyes (CR \& CV) occurred at the 90 minutes. After that the rate of adsorption was found slow. This shows that it can be assumed that the balance is achieved after 45 minutes. This is mainly due to the saturation of the active site which does not allow more adsorption to occur. In general, the adsorption capacity and the color removal efficiency of the adsorbents are directly related to the contact time, thus increasing the adsorption of the surface while increasing the contact time due to increased contact with the dye molecules (CR \& CV) with the adsorbed surface. However, it reaches a fixed value at a specific time. At this moment, the amount of dyes absorbed in a dynamic balance with a quantity not absorbed by the dyes, and after this time, the amount of adsorption of the dyes by the adsorbents is almost constant ${ }^{49}$. After adjust time the adsorbent was filtered from the solution for $15 \mathrm{~min}$. The residual concentration of dye in solution was spectrophotometrically scanned at $\lambda_{\max }=498 \mathrm{~nm}$ for CR and $\lambda_{\max }=590 \mathrm{~nm}$ for CV $(\lambda \max )$ using a UV-Vis spectrophotometer. The \% Adsorption was calculated according to Eq. (1).

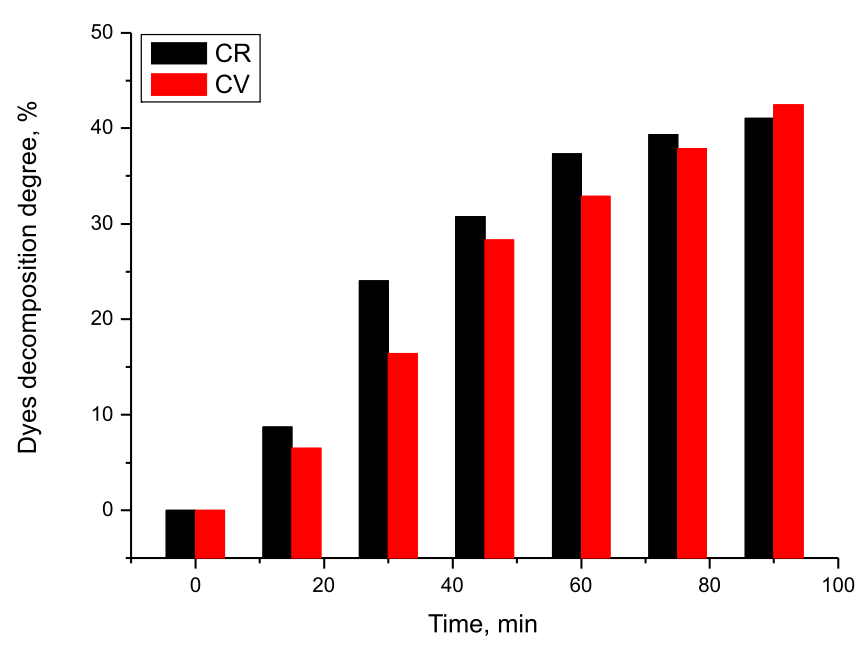

Figure 15. Dyes decomposition degree versus time of Congo Red (CR) and Crystal Violet (CV) dyes treated with $\mathrm{In}_{2} \mathrm{O}_{3}$ NPs at different contact time

\section{Effect of $\mathrm{In}_{2} \mathrm{O}_{3}$ adsorbent doses}

Degradation of the dyes $(\mathrm{CR} \& \mathrm{CV})$ is strongly affected by the amount of $\operatorname{In}_{2} \mathrm{O}_{3}$ NPs adsorbents. The Congo Red (CR) and Crystal Violet (CV) adsorptions were studied on $\mathrm{In}_{2} \mathrm{O}_{3}$ NPs with a change in the adsorbents from 10 $\mathrm{mg}$ to $50 \mathrm{mg} \cdot \mathrm{L}^{-1}$ at a 90 minutes continuous stirring rate with an optimal dye concentration of $50 \mathrm{mg} \cdot \mathrm{L}^{-1}$. It was observed from Figure 16 that by increasing the dose, the adsorption of dyes (CR \& CV) increased the excellent amount of adsorbents. The maximum $>60 \%$ and $>70 \%$ for $\mathrm{CR}$ and $\mathrm{CV}$ dyes, respectively, are adsorbed at a dose of $50 \mathrm{mg}$ of adsorbents. An additional increase in the absorbed dose reduces the absorption rate. This

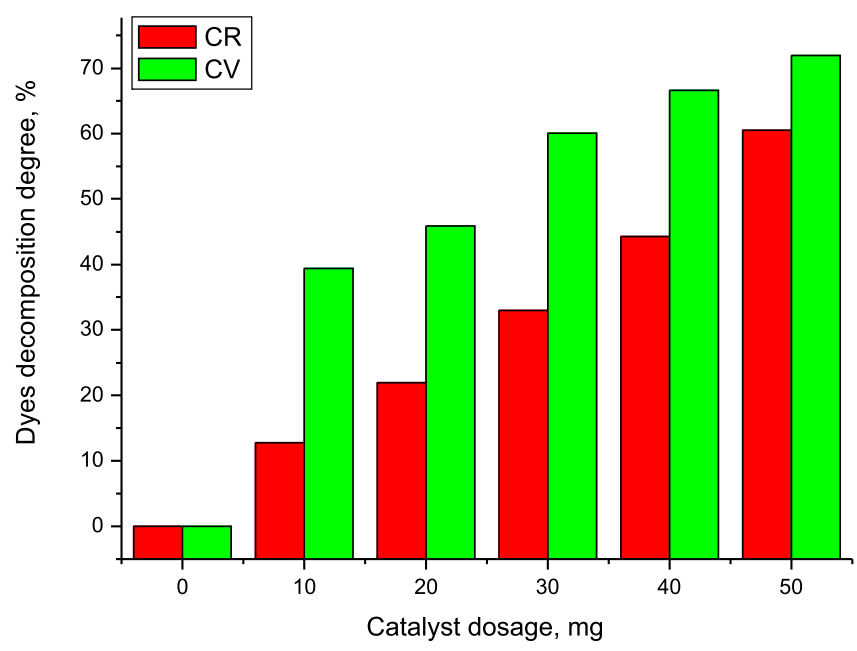

Figure 16. Dyes decomposition degree versus catalyst dosage of Congo Red (CR) and Crystal Violet (CV) dyes treated with different mass doses of $\mathrm{In}_{2} \mathrm{O}_{3}$ NPs 
may be due to overfilling or aggregation of adsorption sites, resulting in a reduction in the available surface area of respected dyes ${ }^{50}$.

\section{Effect of pH value}

The $\mathrm{pH}$ of the photocatalytic degradation process has a significant effect on the adsorption efficiency of most organic dyes. The effect of $\mathrm{pH}$ on adsorption of $\mathrm{CR} \&$ $\mathrm{CV}$ dyes on $\mathrm{In}_{2} \mathrm{O}_{3}$ NPs was performed at $50 \mathrm{mg} \cdot \mathrm{L}^{-1}$ of primary dye concentration with a $50 \mathrm{mg}$ mass of $\mathrm{In}_{2} \mathrm{O}_{3}$ NPs adsorbent at $90 \mathrm{~min}$ of stirring rate at room temperature. As shown in Figure 17, $\operatorname{In}_{2} \mathrm{O}_{3}$ nanoparticles show maximum absorption of $>79 \%$ of represented dyes at $\mathrm{pH} 12$ which decreased at low acidic $\mathrm{pH}$. This assures that low $\mathrm{pH}<7$ is unsuitable for dye absorption by $\mathrm{In}_{2} \mathrm{O}_{3} \mathrm{NPs}$.

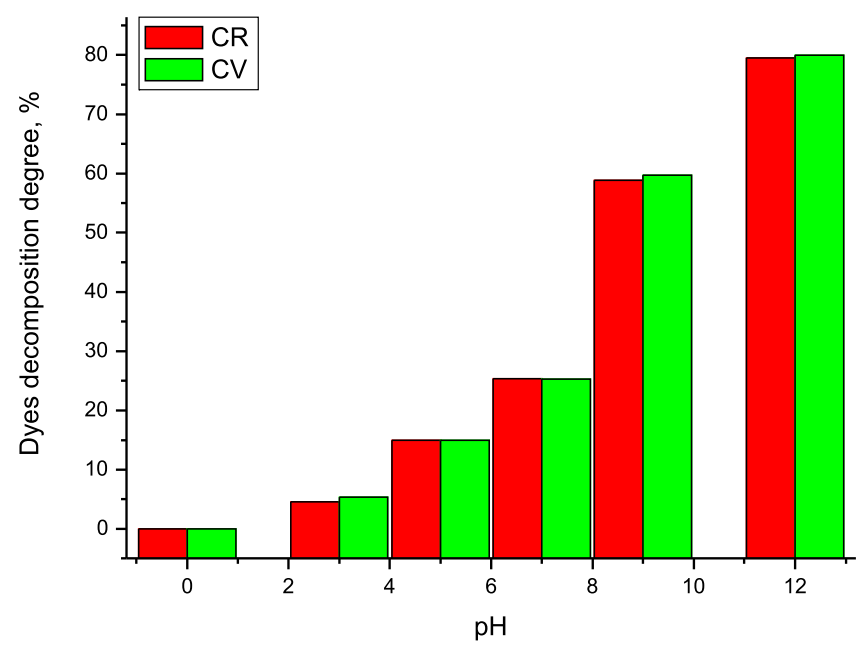

Figure 17. Dyes decomposition degree versus $\mathrm{pH}$ of Congo Red and Crystal Violet dyes treated with different $\mathrm{In}_{2} \mathrm{O}_{3} \mathrm{NPs}$ at different $\mathrm{pH}$

Based on the semi-conductor photovoltaic behavior of the catalyst, the radiation of this catalyst has a wide-band gap energy that leads to the electron pairing of the electron holes. These pairs then spread to the surface, where the electrons adsorbed hydroxide, the hole, and oxygen molecules, to form a hydroxyl radical. Before holes and electrons form on the surface, there is a great chance of recombination ${ }^{51}$.

\section{CONCLUSION}

A nanoparticles of $\operatorname{In}_{2} \mathrm{O}_{3}$ resulting from the thermal decomposition of a $\left[\mathrm{In}\left(\mathrm{CH}_{3}\left(\mathrm{CH}_{2}\right)_{4} \mathrm{COO}\right)_{3}\right]$ complex as a precursor. The assignments of thermal analysis and FT-IR support that during the decomposition of the precursor complex a carbonate molecule is formed. The calcination of this precursor material at temperature $800^{\circ} \mathrm{C}$ gives rise to nanocrystalline particles of cubic $\mathrm{In}_{2} \mathrm{O}_{3}$ with sizes 10-20 nm. Energy band gap was calculated using UV-Vis spectroscopy. Photodegradation studies of $\mathrm{CR}$ and CV dyes on the surface of the $\operatorname{In}_{2} \mathrm{O}_{3}$ NPs were performed with various parameters such as contact time, effect of adsorbent dosage, and effect of $\mathrm{pH}$. The results suggest that the $\operatorname{In}_{2} \mathrm{O}_{3}$ NPs are good photocatalyst for the removal of $\mathrm{CR}$ and $\mathrm{CV}$ dyes.

\section{ACKNOWLEDGEMENTS}

This work was funded by the Deanship of Scientific Research at "Imam Abdulrahman Bin Faisal University", through the Research Groups Program No. 2017-246CED.

\section{LITERATURE CITED}

1. Cisneros, R.L., Espinoza, A.G. \& Litter, M.I. (2002). Photodegradation of an azo dye of the textile industry. Chemosphere, 48(4), 393-399. https://doi.org/10.1016/S0045-6535(02)00117-0.

2. Lee, Y.H. \& Pavlostathis, S.G. (2004). Decolorization and toxicity of reactive anthraquinone textile dyes under methanogenic conditions. Water Res., 38(7), 1838-1852. https:// doi.org/10.1016/j.watres.2003.12.028.

3. Xie, S., Ren, W., Qiao, C., Tong, K., Sun, J., Zhang, M., Liu, X. \& Zhang, Z. (2018). An electrochemical adsorption method for the reuse of waste water-based drilling fluids. Natural Gas Industry B, 5(5), 508-512. https://doi.org/10.1016/j. ngib.2018.03.005.

4. Zhao, Z., Geng, C., Yang, C., Cui, F. \& Liang, Z. (2018). A novel flake-ball-like magnetic $\mathrm{Fe}_{3} \mathrm{O}_{4} / \gamma-\mathrm{MnO}_{2}$ meso-porous nano-composite: Adsorption of fluorinion and effect of water chemistry. Chemosphere, 209, 173-181. https://doi.org/10.1016/j. chemosphere.2018.06.104.

5. Radhakrishnan, A., Rejani, P., Khan, J.S. \& Beena, B. (2016). Effect of annealing on the spectral and optical characteristics of nano $\mathrm{ZnO}$ : Evaluation of adsorption of toxic metal ions from industrial waste water. Ecotoxicology and Environmental Safety, 133, 457-465. https://doi.org/10.1016/j. ecoenv.2016.08.001.

6. Basheer, Al Arsh. (2018). New generation nano-adsorbents for the removal of emerging contaminants in water. $J$. Molec. Liquids, 261, 583-593.

7. Mehrotra, R.C. \& Bohra, R. (1983). Metal Carboxylates, Academic Press, London.

8. Brusau, E.V., Pedregosa, J.C., Narda, G.E., Ayala, E.P. \& Oliveira, E.A. (2004). Vibrational and thermal study of hexaaquatris (malonato) dieuropium (III) dihydrate. J. Arg. Chem. Soc., 92(1/3), 43-52.

9. Gushchina, T.N. \& Kotenko, G.A. (1983). Koord. Khim., 12(3), 325.

10. Brzyska, W. \& Paszkowska, B. (1998). Studies on the Thermal Decomposition of Rare Earth Caproates. J. Thermal Anal., 51, 561-566. https://doi.org/10.1007/BF03340193.

11. Doyle, A., Felcman, J., Gambardella, M., Verani, C.N. \& Tristao, M.L.B. (2000). Anhydrous copper(II) hexanoate from cuprous and cupric oxides. The crystal and molecular structure of $\mathrm{Cu}_{2}\left(\mathrm{O}_{2} \mathrm{CC}_{5} \mathrm{H}_{11}\right)_{4}$. Polyhedron, 19(26/27), 2621-2627. https:// doi.org/10.1016/S0277-5387(00)00568-4.

12. Pietsch, R. (1971). Untersuchungen über die extraktion von thorium, blei und eisen (III) als verbindungen der capronsäure. Anal. Chim. Acta, 53(2), 287-294. https://doi.org/10.1016/ S0003-2670(01)82087-0.

13. Kolomiets, L.L., Lysenko, O.V. \& Pyatnitskii, I.V. (1988). Photoelectric counter of disperse particles. Z. Anal. Khim., 43(10), 1773.

14. Pyatnitskii, I.V., Kolomeits, L.L., Lysenko, O.V. \& Sobko, M.G. (1990). Z. Anal. Khim., 45(1), 56.

15. Kopacz, S., Szantula, J. \& Pardela, T.Z. (1989). Prikladoni Khim, 62(11), 2535.

16. Mazouchi, M., Sarkar, K., Purahmad, M., Farid, S. \& Dutta, M. (2018). Photoconduction mechanism of ultra-long indium oxide nanowires. Solid-State Electronics, 148, 58-62. https://doi.org/10.1016/j.sse.2018.07.003.

17. Du, X. \& Man, B. (2018). Effect of growth temperature on the structural and optoelectronic properties of epitaxial indium oxide films. J. Crystal Growth, 499, 18-23. https://doi. org/10.1016/j.jcrysgro.2018.07.033. 
18. Fuchs, F. \& Bechstedt, F. (2008). Indium-oxide polymorphs from first principles, Quasi particle electronic states. Phys. Rev., 77(4), 55107-55109. https://doi.org/10.1103/PhysRevB.77.155107.

19. Li, C., Zhang, D., Han, S., Liu, X., Tang, T. \& Zhou, C. (2003). Diameter-Controlled Growth of Single-Crystalline $\mathrm{In}_{2} \mathrm{O}_{3}$ Nanowires and Their Electronic Properties. Adv Mater. 15(2), 143-146. https://doi.org/10.1002/adma.200390029.

20. Falcony, C., Kirtley, J.R., Dimaria, D.J., Ma, T.P. \& Chen, T.C. (1985). Electroluminescence emission from indium oxide and indium-tin-oxide. J. Applied Phys., 58, 3556-3558. https:// doi.org/10.1063/1.335730.

21. Mane, R.S., Pathan, H.M., Lokhande, C.D. \& Han, S.H. (2006). An effective use of nanocrystalline $\mathrm{CdO}$ thin films in dye-sensitized solar cells. Solar Energy, 80(2), 185-190. https:// doi.org/10.1016/j.solener.2005.08.013.

22. Zhang, D., Liu, Z., Li, C., Tang, T., Liu, X., Han, S., Lei, B. \& Zhou, C. (2004). Detection of $\mathrm{NO}_{2}$ down to ppb Levels Using Individual and Multiple $\mathrm{In}_{2} \mathrm{O}_{3}$ Nanowire Devices. Nano. Lett., 4(10), 1919-1924. https://doi.org/10.1021/nl0489283.

23. Karazhanov, S.Z., Ravindran, P., Vajeeston, P., Ulyashin, A., Finstad, T.G. \& Fjellvag, H. (2007). Phase stability, electronic structure, and optical properties of indium oxide polytypes. Phys. Rev. B, 76, 75129-75131. https://doi.org/10.1103/ PhysRevB.76.075129.

24. Lin, S.E. \& Wei, W.C.J. (2008). Synthesis and Investigation of Submicrometer Spherical Indium Oxide Particles. J. Am. Ceram. Soc., 91(4), 1121-1128. https://doi.org/10.1111/j.1551$-2916.2008 .02266 . x$.

25. Chu, D.Y.P., Zeng, D.J. \& Xu, J. (2007). Tuning the phase and morphology of In2O3 nanocrystals via simple solution routes. Nanotechnology. 18(43), 5605-5609.

26. Rey, J.F.Q., Plivelic, T.S., Rocha, R.A., Tadokoro, S.K., Torriani, I. \& Muccillo, E.N.S. (2005). Synthesis of $\operatorname{In}_{2} \mathrm{O}_{3}$ nanoparticles by thermal decomposition of a citrate gel precursor. J. Nanopart. Res., 7(2), 203-208. https://doi.org/10.1007/ s11051-004-7899-7.

27. Geary, W.J. (1971). The use of conductivity measurements in organic solvents for the characterisation of coordination compounds. Coord. Chem. Rev., 7(1), 81-122. https://doi. org/10.1016/S0010-8545(00)80009-0.

28. Deacon, G.B. \& Phillips, R.J. (1980). Relationships between the carbon-oxygen stretching frequencies of carboxylato complexes and the type of carboxylate coordination. Coord. Chem. Rev., 33, 227-250. https://doi.org/10.1016/S00108545(00)80455-5.

29. Alcock, N.W., Culver, J. \& Roe, S.M. (1992). The Effects of Cations and Anions on the Ionic of the development of organic substitution methods. J. Chem. Soc. Dalton Trans., 1447.

30. Nakamoto, K. (1997). Infrared and Raman Spectra of Inorganic and Coordination Compounds, Wiley, New York.

31. Dunn, D.D. \& Hall, R.H. (1975). Purines, pyrimidines, nucleosides, and nucleotides: Physical constants and spectral properties, in G.D. Fasman (Ed.), Handbook of Biochemistry and Molecular Biology, 3rd ed., Nucleic Acids, Vol. 1, CRC Press, Cleveland, Ohio, pp. 65-215.

32. Holm, R.H. \& Cotton, F.A. (1958). Spectral Investigations of Metal Complexes of $\beta$-Diketones. I. Nuclear Magnetic Resonance and Ultraviolet Spectra of Acetylacetonates. $J$. Am. Chem. Soc., 80, 5658. https://doi.org/10.1021/ja01554a020.

33. Cotton, F.A. \& Wilkinson, C.W. (1972). Advanced Inorganic Chemistry, $3^{\text {rd }}$ Ed, Interscience Publisher, New York.

34. Refat, M.S., El-Korashy, S.A., Kumar, D.N. \& Ahmed, A.S. (2008). FTIR, magnetic, ${ }^{1} \mathrm{H}$ NMR spectral and thermal studies of some chelates of caproic acid: Inhibitory effect on different kinds of bacteria. Spectrochimica Acta Part A, 70(1), 217-233. https://doi.org/10.1016/j.saa.2007.07.036.

35. Coats, A.W. \& Redfern, J.P. (1964). Kinetic Parameters from Thermogravimetric Data. Nature, 201, 68-69.
36. Horowitz, H.W. \& Metzger, G. (1963). A New Analysis of Thermogravimetric Traces. Anal. Chem., 35, 1464-1468. https://doi.org/10.1021/ac60203a013

37. Zsako, J. (1968). Kinetic analysis of thermogravimetric data. J. Phy. Chem., 72(7), 2406-2411. https://doi.org/10.1021/ j100853a022.

38. Sharp, J.H. \& Wentworth, S.A. (1969). Kinetic analysis of thermogravimetric data. Analyt. Chem., 41(14), 2060-2062. https://doi.org/10.1021/ac50159a046.

39. Wendlandt, W.W. (1974). Thermal Methods of Analysis, John Wiley \& Sons, New York, NY, USA, $2^{\text {nd }}$ edition.

40. Cullity, B.D. (1978). Elements of X-Ray Diffraction, Second Edition, Addison-Wesley Publishing Company, ch. 5.

41. Nyquist, R.A. \& Kagel, R.O. (1971). In: Infrared Spectra of Inorganic Compounds. Academic Press, New York, Vol. 4.

42. Keller, R.J. (1982). In: The Sigma Library of FTIR Spectra, Sigma Chemical, St. Louis, Vol. 2.

43. Mondal, A. \& Ram, S. (2004). Reconstructive phase formation of $\mathrm{ZrO}_{2}$ nanoparticles in a new orthorhombic crystal structure from an energized porous $\mathrm{ZrO}(\mathrm{OH})_{2} \cdot x \mathrm{H}_{2} \mathrm{O}$ precursor. Ceramics International, 30, 239. https://doi.org/10.1016/S02728842(03)00095-6.

44. Mott, N.F. \& Davis, E.A. (1979). Electronic Processes in NonCrystalline Materials, $2^{\text {nd }}$ ed., Clarendon Press, Oxford.

45. Li, C., Zhang, D., Han, S., Liu, X., Tang, T., Lei, B., Liu, Z. \& Zhou, C. (2003). Synthesis, Electronic Properties, and Applications of Indium Oxide Nanowires. Ann. N.Y. Acad. Sci., 1006, 104-121. DOI: 10.1196/annals.1292.007.

46. Sreenivas, K., Rao, T. \& Mansingh, A. (1985). Preparation and characterization of rf sputtered indium tin oxide films. $J$. Appl. Phys., 57, 384-392. https://doi.org/10.1063/1.335481.

47. Shigesato, Y., Takaki, S. \& Haranoh, T. (1992). Electrical and structural properties of low resistivity tin-doped indium oxide films. J. Appl. Phys., 71, 3356-3364. https://doi. org/10.1063/1.350931.

48. Rey, J.F.Q., Plivelic, T.S., Rocha, R.A., Tadokoro, S.K., Torriani, I. \& Muccillo, E.N.S. (2005). Synthesis of $\operatorname{In}_{2} \mathrm{O}_{3}$ nanoparticles by thermal decomposition of a citrate gel precursor. J. Nanoparticle Res., 7, 203-208. https://doi.org/10.1007/ s11051-004-7899-7.

49. Ghanizadeh, G.H. \& Asgari, G. (2009). Removal of Methylene Blue Dye from Synthetic Wastewater with Bone Char. Iran. J. Health Environ., 2, 104-113. http://ijhe.tums.ac.ir/ article-1-159-en.html.

50. Farzin, N., deh Hossein, N., Shahram, N., Asif, M., Inderjeet, T., Shilpi, A. \& Kumar, G.V. (2016). Removal of malachite green from aqueous solutions by cuprous iodidecupric oxide nano-composite loaded on activated carbon as a new sorbent for solid phase extraction: Isotherm, kinetics and thermodynamic studies. J. Mol. Liq., 213, 360-368. https:// doi.org/10.1016/j.molliq.2015.07.058.

51. Tang, C.W. (2013). Study of Photocatalytic Degradation of Methyl Orange on Different Morphologies of ZnO Catalysts. Modern Research in Catalysis, 2, 19-24. http://dx.doi.org/10.4236/ mrc.2013.22003. 